\title{
Kuram ve Pratik Arasinda Peyzaj: Kentin Karşıtı mı, Kentsel Süreçlerin Katalizörü mü?
}

\author{
Ebru Bingö ${ }^{1}$ \\ ORCID: 0000-0002-7194-0070
}

Öz

Michel Foucoult (1997)'a göre, bahçeler, toplumsal normlara dâhil olmayan, mevcut üretim tarzı ile ilişkili olmayan, mevcut erk ve baskın ideoloji tarafindan türdeşleştirilmeyen alanlar olarak heterotopya mekanlarmdan biridir. Peki ya peyzaj da bu sinıfa girmekte midir? Bu yazı, peyzajı ana çalışma alanı olarak tanımlayan peyzaj mimarlığı kuramı ve pratiklerinde bu sorunun cevabını aramaktadır. Yirminci yüzyıl başında Amerika'da peyzaj mimarlığı disiplini içerisinde kurumsallaşmasından günümüze kadar peyzaj kavramına, heterotopya fikrini çă̆rıştıracak şekilde, kentin ötekisi, pastoral estetik, pasif bir kent parçası, ya da alternatif bir kentleşme modeli gibi değişen anlamlar yüklenmiştir. Bu makale, peyzajın kuramsal olarak kentin karşısında konumlandırllma biçimlerini ortaya koymakta, ancak buna ră̆men pratiklerinin kentsel dinamiklerle ve kapitalist birikim süreçleriyle ilişkilerini ortaya koymaktadır. Yazının amacı, literatür taraması ve gömülü teori araştırma modelini kullanarak, heterotopya olarak peyzajın kentsel üretim biçimleriyle ayrı tutulamaz ilişkisini ortaya koymak ve peyzaj kavramına kuramsal ve pratiksel bir bütünlükle yaklaşmanın olasılıklarına ışık tutmaktadır.

Anahtar Kelimeler: peyzaj, kent, heterotopya, peyzaj mimarlı̆̆ kuramı, kentsel süreçler, peyzaj mimarlı̆̆l, kuram ve pratik 


\title{
Landscape in-between Theory and Practice: Antithesis to the City or Catalyst of Urban Processes?
}

\author{
Ebru Bingö ${ }^{2}$ \\ ORCID: 0000-0002-7194-0070
}

\begin{abstract}
According to Michel Foucoult (1997), gardens are one of the heterotopia spaces that are not included in social norms, irrelevant to the existing mode of production, and cannot be homogenized by the existing power and dominant ideology. But does landscape fall into this category? This article seeks answer to this question in landscape architecture theory and practices whose main area of study is landscape. Since the institutionalization of landscape architecture discipline in America at the beginning of the twentieth century until today, various meanings has been attributed to the concept of landscape such as the other of the city, pastoral aesthetics, passive urban part, or an alternative urbanization model, that were evoking the idea of heterotopia. Using literature review and embedded theory research model, this article points out the theoretical positions of landscape against the city as heterotopia, nevertheless how their responses in spatial practices are related to urban dynamics and capitalist accumulation processes. The aim of the article is to reveal the inseparable relationship between landscape and urban processes and to shed light on the possibilities of evaluating the concept of landscape with a theoretical and practical integrity.
\end{abstract}

Keywords: landscape, city, heterotopia, landscape architecture theory, urban processes, landscape architecture, theory and practice

${ }^{2}$ Asst. Prof. Dr. Hatay Mustafa Kemal University, E-mail: ebrubingol@yahoo.com

idealkent (c) Kent Araştırmaları Dergisi (Journal of Urban Studies)

http://idealkentdergisi.com

Geliş Tarihi Received Date: 29.07.2020 Kabul Tarihi Accepted Date: 16.04.2021 


\section{Giriş}

Michel Foucoult, toplumsal norm ve hegemonya süreçlerine dâhil olmayan, öteki mekân olarak adlandırabileceğimiz farklılığın mekânlarını, heterotopya olarak adlandırır. Heterotopya, egemen üretim tarzı ile ilişkili olmayan, mevcut erk ve baskın ideoloji tarafından türdeşleştirilmeyen mekânlardır. Foucoult (1997), tekil bir mekân içerisinde var olan, birden fazla anlam katmanları ve(ya) diğer yerlerle ilişkileri olmasına karşın birbirleriyle ve içinde bulundukları bağlamla bağdaşık olmayan bahçeleri, heterotopya mekânlarından biri olarak sinıflandırır. Bu makale, peyzajı üreten disiplinlerden biri olan peyzaj mimarlığı disiplini içerisinde, yirminci yüzyıl başında Amerika'da mesleğin kurumsallaşmasından günümüze kadar peyzaj kavramının kuramsal olarak doğa ve kent ilişkisinde farklı anlamlandırılma ve konumlandırılma biçimlerine ışık tutmaktadır. Peyzaja atfedilen anlamlar, üretildikleri dönemin yaşam biçimi, üretim modelleri, düşünce biçimlerinden etkilenir. Peyzaj kavramı, heterotopyayı çağrıştıracak şekilde, zaman zaman öteki, zaman zaman pasif, kentin zıttı doğa parçası, zaman zaman pastoral bir estetik, alternatif bir yaşam modeli gibi farklı anlamlar yüklenir. Her ne kadar anlamsal içeriği değişiklik gösterse dahi, kent içerisinde peyzaj olarak adlandırdığımız ortamların, ilk çağrışımı, kentin öteki mekânları olduğu yönündedir. Bunun yanında makale, peyzaj mimarlığı pratiklerinde peyzajin kentsel süreçlerle ve kapitalist birikim süreçleriyle ilişkisini ortaya koymaktadır. Pratikte peyzaj, kentin içerisinde mevcut erk tarafından kabul edilen izotopik mekânlara [isotrophy] dönüştürülmedikçe varlığını sürdüremez. Peyzaj, tanımlanma biçimi, "kentin zıttı", "öteki", yeni bir kentleşme modeli gibi heterotopya çeşitleri içerse dahi, kent içerisinde varlığını sürdürebilmek için heterotopya sınırlarının dışına çıkmak, kentsel süreçlerle işbirliği yapmak ve kentin dinamikleriyle hemhal olmak zorunda kalır. Yazının amacı, peyzajın kuram içerisindeki tanımlanma biçimleri ve kentsel üretim biçimleri arasındaki çelişkileri ortaya koyarken bütünlüklü bir kuram-pratik ortamının olasılıklarını aramaktır.

\section{Yöntem}

Makalenin çizdiği çerçeve, kuramsal olarak peyzaj kavramının, kavramla en yakından ilişkili meslek alanı olarak peyzaj mimarlığı disiplini içerisinde üretiliş biçimlerini, tarihsel ve kronolojik bir süreçte incelemektir. Disiplin içerisinde peyzaj kavramının çok çeşitli üretim biçimleri olmakla birlikte bu makale, peyzaj mimarlığının kurumsallaştığı ve eğitim kurumlarının açıldı- 
ğ1 yirminci yüzyıldan günümüze kadar ön plana çıkmış ve disiplinin pratiğini de etkilemiş kuramsal yaklaşımlara odaklanmaktadır. Makalenin yöntemi olarak, literatür taraması ve gömülü teori araştırma modeli kullanılmaktadır. Makale, peyzaj kavramının kuram içerisinde heterotopya ile ilişkili tanımlanma biçimlerini ve bu kuramsal yaklaşımların, mekansal pratikteki karşılıklarını araştırmakta ve karşılaştırmaktadır. Bu karşılaştırma kuram ve pratik arasındaki uyuşmazlığa 1şık tutmaktadır. Bu uyuşmazlığı net bir şekilde karşılaştırabilmek için Şekil 1. hazırlanmıştır.

\section{Muğlak Bir Kavram Olarak Peyzaj}

Peyzaj kelimesi, ilk olarak Frizye dilinde landschop olarak toprak parçası anlaminda kullanılır. Peyzaj kavraminin landskipe ya da landscaef kelime karşılıkları ile kullanımı, Britanya'ya Anglo-Saxon köklerden gelmektedir (Jackson, 1984). Kelimenin anlamı, çiftçilik yapılan ve insan eliyle dönüştürülen arazilerin, ormanların ve meraların , tarım yolu ile kavuştuğu kırsal niteliği ifade etmektedir (Taylor, 2008). Latin dillerinde pagus, Fransizcada pagus, paysage, campagne kentin dışındaki araziler anlamına gelen, kırsal bir bölgeye işaret eden, peyzaj ile ilişkili kullanılan diğer kelimelerdir (Jackson, 1984). Peyzaj kavramı, 16.yüzyıl İngiliz diline landskip olarak tercüme edilir ve zamanla kelimenin anlam karşıllı̆̆, manzara olarak değişir. 17. yüzyıl Avrupa'sında, özellikle İngiltere'de, peyzajı idealize ederek resmeden Hollanda gerçekçi peyzaj okulu [lantskip] ve Claude Lorrain'in düşsel tarihsel resimleri ile eşleştirilmiştir (Taylor, 2008, s.2). Bu dönemde peyzaj, görme eylemi ile ilişkilendirilmiş, gözün gördüğü manzara ile eşleştirilmiştir (Jackson, 1984, s.8). 18.yüzyıl sonlarında görülmeye başlayan ve 19.yüzyılda kuramsal tartışmaları alevlenen pitoresk (resimsi) İngiliz bahçeleri, peyzaj kavramının, manzara anlamını destekler şekilde, kıvrılan yollar, anlamlı açıklıklar, özellikle yürüyen insana değişen görsel deneyimi sunmak üzere tasarlanır. 19.yüzyıl sonrası, kelimenin kavuştuğu anlam, Mikesell'in (1968), tariflediği biçimiyle "üzerindeki bütün nesnelerle beraber gözün bir kerede görebileceği bir arazi ya da alan" dır.

Günümüzde, peyzaj kavramına dair betimlemeler, tanımlamalar ve görselleştirmeler, edebiyat, resim, şiir, dokuma, mitler, bahçeler, tarih gibi çok farklı alanda sıklıkla karşımıza çıkmaktadır (Taylor, 2008). Bunun sebebi, peyzaj kavramının, sabit, statik bir kavram ya da imge olmaması ile ilişkilidir. Dolayısıyla, peyzajın tanımlanma biçimleri sıklıkla değişmekte, farklı söylemlere konu olmakta, retorik olarak farklı zeminlerde değerlendirilmektedir. Meining'de ifade ettiği gibi "peyzaj, çekici, önemli ve muğlak bir 
terimdir ve bizim vizyonumuzca belirlenen ve zihinlerimiz tarafindan yorumlanan bir olgudur" (Meinig, 1979, s.1-2). Peyzaj kavramını tanımlanmasında vizyonumuzu belirleyen şey, yaşanan dönemin yaşam ve üretim ilişkileri ve bunlara bağlı olarak değişim gösteren düşünce dünyasıdır. Peyzaj gibi değişken bir kavramla ilişkili kuramsal yaklaşımlar ve pratikler, tarihsel süreç içerisinde dönemin kentsel, sosyal, bilimsel, ideolojik yapısı ile ilişkili olarak birçok değişime uğramaktadır. Peyzaj mimarlığı kuramında peyzaj, kent, doğa, ekoloji üçgeninde kaygan bir zeminde konumlanmakta, zaman içerisinde yaşam biçimleri değiştikçe, yer yer kentsel bozulma karşısında bir kurtarıc1, yer yer kenti kurtaracak biyolojik bir sistem, yer yer kentin yaşam potansiyelini arttıracak büyük boşluklar, yer yer de kentin gelişimini yönlendirecek bir süreç, yer yer de kentsel süreçlerle işbirliği yapan, neo-liberal üretim biçimlerini meşrulaştırıcı bir araç olabilmektedir.

\section{Peyzaj: Kenti Sağaltıcı bir Araç}

Erken dönem peyzaj mimarlığı disiplini, kelimenin manzara anlamını karşılayacak şekilde, özellikle İtalyan formal tasarımı ya da İngiliz pitoresk bahçesinin biçimsel tasarımına odaklanan özel bahçelerin tasarımına dayanır. Mesleğin kurumsallaşması ve içeriğini genişletmesi, 1901 yılında Harvard Üniversitesi'nde Frederick Law Olmsted Jr.'ın (1870-1957) babası ve peyzaj mimarlığı meslek disiplininin kurucusu olan Frederick Law Olmsted'in alanındaki kuramsal ve pratik bilgisini, bölümünün resmi eğitim program1na aktarması ile olur.

Frederick Law Olmsted (1822-1903), Mikesell'in "manzara olarak peyzaj" tanımlamasını, kamu sağlığına katkı sağlamak hedefi ile bir araya getirir. Peyzaj, yani doğayla ideal uyumu yakalamak üzere dönüştürülmüş manzara, "[sanayi] kentinin yaşamının insanı yiyip bitiren entellektüel çatışmasindan uzaklaşma sağlamakta"(Olmsted, 1886, s.21) ve fiziksel, zihinsel ve ahlaki etkileri ile etkileyici bir karakter sunmaktadır. Özellikle havanın ve alışkanlıkların değişimi ile gündelik rutinden kaçı̧̧a, insanın rahatlamasına, akılda herhangi bir amaç olmaksızın anın tadını çıkarmasına, günün stresinden ve geleceğe dair endişelerden uzaklaşmasına ve aklı ve bedeni tazelemesine neden olduğu için değerlidir (Spirn, 1995, s. 93). Olmsted için manzara, sanayi kentlerinin çirkinliğine ve sağlıksızlığına karşı ve kentin zıt karakterine sahip, kıvrılan yolları, göletleri, geniş çimenlikleri ile doğanın karmaşık ve anlaşılamaz yapısını taklit etmelidir. Bu sebeple, Olmsted'in parkları, keskin bir şekilde kent dokusundan ayrılmakta, kentin ızgara yerleşmesinin tam tersi olarak peyzaj, içerisinde yürüyüş yolları, nazik eğimler 
ve yumuşak formlarla manzaraya akmaktadır. Peyzaj vePastoral estetiği ile ön plana çıkan parkların üretimi sanatsal bir üretimdir ${ }^{3}$. Park içerisinde hareket ile yepyeni algilar, deneyimler ve hayalgücü olasilıkları sunmaktadır (Spirn, 1995). Olmsted, belirgin şekilde hayal gücünü, akıldan ayıran ve akıldan çok algıya odaklanan, gerçekliğin basit ve dolaysız insan deneyimine dönmek olduğuna inanan Johh Locke felsefesi (Erten, 2009) ile bu felsefenin estetiği olabilecek romantik idealizmin estetiğinden etkilenir. Bu düşüncenin altında, doğayla uyumlu bir ilişki kurmanın, insanı ahlaki açıdan da yücelteceği, "bozulmamış doğanın" ya da idealize edilen doğanın tini bozulma ve kirlenmeden arındıracağı düşüncesi yatmaktadır (Erten, 2009, s. 38).

Frederick Law Olmsted'in kent yaşamına karşı kamusal peyzajları gündeme getirmesinin arkasında özellikle kamu sağlığı vurgusu vardır. Peyzaj kavramına modern bakış açısı, peyzajin sadece doğal bir öge değil, "kültürel süreçler tarafından şekillenen bir olgu" (Taylor, 2008, s.1) olduğu kabul edilirse, bu yaklaşımın Olmsted ile başladığı söylenebilir. Bugün ekosistem hizmetleri olarak bildiğimiz yaklaşımın temelini oluşturan doğa ve insan refahı arasındaki bağlantı Olmsted tarafından kurulmuştur (Eisenman, 2013, s. 290). Olmsted, halkın refahının sadece sosyo-ekonomik gelişmeler aracılığıyla değil, kültürel ve ekolojik dinamikler üzerinden çözümlenmesi gerektiğini ve doğanın zihinsel sağlık, stres ve toplumsal uyum üzerindeki yararlı etkisini savunmaktadır. Olmsted, iyi manzaranın getirdiği psikolojik rahatlama yanında, parklardaki su sistemlerini düzenleyerek ve salgın hastalıkları önleyerek kamu sağlığı problemlerine yönelik işlevsel çözümler geliştirir. Birbirine bağlı parklardan oluşan Emerald Necklace sistemindeki Back Bay Fens ve Muddy River'da kanalizasyon sisteminin oluşturulması, bataklık alanların ve yağmur suyunun sisteminin düzenlenmesi, tuz bataklığının ekolojik restorasyonu yaklaşık yirmi yıl sürmüştür (Eisenman, 2013).

1865 'te Olmsted, ortağı Calvert Vaux ile, Brooklyn kentinin yeşil alanlarını, park içi yolları ile bağlayarak, kentin çeperindeki banliyölere kadar uzanan, zihinsel sağlık ve rekreasyon ihtiyaçlarına cevap verecek bir yeşilmavi sistem kurgular. Olmsted ve Vaux'e göre, bu yeşil-mavi sistem, farklı halk kitlelerinin parklara, kamusal bahçelere, su yollarına, kıyılara, göllere, bataklık alanlara ve spor alanlarına, kısaca rekreasyon alanlarına erişimini kolaylaştırmak üzere mutlaka bütüncül olarak kurgulanmalıdır: "yaptığımız plan bütüncül olarak değerlendirilmelidir. büyük tek bir park, odaklanılan tek

\footnotetext{
${ }^{3}$ Olmsted, Boston kenti için yaptığı tasarımların "Amerikan peyzaj mimarlığı için "sanat alanında yeni bir sayfa" açacağını vurgulamaktadır (Spirn, 1995, s. 104).
} 
nokta olmamalı; insanlara güvenli tazelenme, rekreasyon ve sağlık olanakları sağlamak için daha büyük ve bütüncül bir düzenlemenin sadece bir parçası olarak görülmelidir" (Olmsted, 1868, s.18).

Olmsted, halk sağlığını koruma amacıyla kent ölçeğinde, kentsel dokudan ayrı ama kendi içerisinde birbirine bağlanan yeşil alanlar tasarlamaya çalışır. Öyle gözükmektedir ki, Olmsted'e göre doğa(l) manzara, farklı halk kitleleri tarafından ulaşılabilir olacak ve böylece sanayi kentlerinin içerisinde halk sağlı̆̆ını sağlayacaktır:

"kentler öyle yayılmıştır ki kırlara erişmek için saatler harcanmakta, boş arazilere ulaşılınca ise buralara girişler yasaklanmıştır. Bu sebeple, buraların serbest kullanımı arttırmak ve insanların tadını çıarmaları için komşu boş arazileri, ormanlıkları, havuz kenarlarını, nehir yataklarını, vadileri ya da tepeleri olabildiğince arttırmak, [kent ya da kır] herhangi birinin iyi manzarasını yaygınlaştırmak gereklidir" (Olmsted, 1895, s.253-54).

Olmsted'den sonra kent karşıtı peyzaj anlayışı, F.L.Wright, E. Howard ve Le Corbusier gibi birçok modern mimarlık ve şehircilik öncüleri de kent ve kır ilişkisi üzerine öneriler geliştirmişlerdir. Kır ya da peyzaj, ya Ebenezer Howard'ın Bahçe Şehir (1890) ve Frank Lloyd Wright' in Yayılan Şehir Modellerindeki (1932) gibi kentin kusurlarını düzeltecek sosyal bir araç olarak yüceltilen bir olgu, ya da Le Corbusier'in Çağdaş Kent'inde [Ville Contemporaine] olduğu gibi kentin içinde doğal hali ile düzensizliğin, karmaşanın ve irrasyonel olanın temsilidir. Her iki yaklaşımda da, tıpkı Foucoult'ın heterotopya örneğinde olduğu gibi kır ya da peyzaj, ötekidir. Yaşadığı dönemin kent-kır ya da kent-doğa ikileminde, F. L. Olmsted'in söylemleri, proje ortamları ya da peyzajları (dönemin) kentleşme paradigmasına karşı ya da 'öteki' olarak görülmüştür. Ancak, Olmsted'in peyzajı, kentin ötekisi olan heterotopyadan sıyrılmaktadır. Olmsted, doğa aracılığı ile insan yaşamını ilişkilendirerek yeni yaşam formları ve yeni bir kentleşme modeli önermiştir. Çünkü O'na göre peyzaj, öteki ve pasif olma rolü yerine kentsel süreçlerle uyum sağlayabilir. Olmsted, Central Park'ın uygulama aşamasında, arzuladığı pastoral vistaları, doğal havuzları ve arazi biçimlerini elde etmek için, yaklaşık beş milyon metreküp toprak ve kayayı yerinden taşıtmış ve 183 km'lik drenaj borusu döşetmiştir (Eisenman, 2013, s. 292). Olmsted, Yosemite Milli Parkı'nın koruma ve planlama çalışmalarında da benzer şekilde davranır. Çalışma raporlarında Yosemite'nin kutsal niteliklerinden bahsetse dahi, ileride gelişecek peyzajın tanrısal bir yüceliğin temsili olacağına inandığı için, ağaçların kesilmesini ve manzaranın yeniden düzenlen- 
mesini tercih etmektedir (Spirn, 1995, s. 112) ${ }^{4}$. Tipkı 1929'da inşa edilen Long Island Jones Plajı Eyalet Parkı'nın Berman (2004) tasvirinde olduğu gibi, doğa vahşi halinden kökten farklı berrak, dümdüz ve göz kamaştırıc1dır ve doğal olanın gösterişli bir şekilde sergilendiği bir kamusal mekânın yaratılmaktadır (Berman, 2004). Bu anlamda, referanslarını, ne mevcut doğadan, ne de mevcut kentten almaktadır. Olmsted'in halk sağlı̆̆1 ve kamusal ruhun uyanışı üzerine geliştirdiği tasarımlar, referanslarını herhangi bir stilden değil ama Olmsted'in aklındaki "üretilen doğa" ${ }^{5}$ imgesinden almaktadir.

Olmsted'in peyzaj tanımının, kenti iyileştirici bir araç olmasl, kentin içinde bir vaha yaratmak arzusu taşıması ve yeşil alanlara eşit erişimin önemi konusuna hassasiyet göstermesi sebebiyle insan merkezli ${ }^{6}$ hedefler taşıdığ1 söylenebilir (Spirn, 1995, s. 95). Ancak, dönemin politik üretimlerine ve hegemonya süreçlerine dahil olmaktan kaçamaz. Olmsted, 1893'te rol aldığ 1 Chicago'daki Dünya Kolombiyası Sergisi'nde kentin kamusal alanlarında, kenti güzelleştirme adı altında, beyaz Beaux- art üslupta kamu yapıları etrafında, oluşturduğu lagünler ve sert zeminler ile, kamusal alan ilişkilerini yeniden ele alarak kente kamusal ruhun uyanışını tetiklemektedir (Wilson, 1980). Sergi, arka planında, Amerikan şehirlerinin kötü koşullarını tedavi etme, Avrupa kentlerini Amerikan kentlerine adapte etme ve güçlü bir belediye yönetimi imajı verme arzusu taşımaktadır (Krueckeberg, 1994). Olmsted, kentin yönetici sınıfı ve kentin önde gelen aristokrat aktörleri ile işbirliği halinde Amerikan kamusunun gücünü göstermektedir. Bu anlamda, peyzaj, kentin dinamikleri ile birlikte çalışmaktadır. Olmsted, peyzajın kentsel süreçlerle ilişkilenerek var olabilmesinin mümkün olduğunu ve hatta böylece peyzajın kenti yönlendirebileceğinin farkındadır. Pahl'un kent

\footnotetext{
${ }^{4}$ Spirn, Olmsted'in, yirminci yüzyıl düşünürlerinden John Muir'in doğayı bir "tapınak" olarak gören yaklaşımı ve Gifford Pinchot'un doğayı bir "atölye" olarak gören yaklaşımı arasında bir pozisyon benimsediğini ifade etmektedir (Spirn, 1995, 112). Olmsted için peyzaj, doğanın karş1sında saygıyla eğilme ile onu değiştirerek kullanma arasında bir sanat alanıdır.

${ }^{5}$ Olmsted, "üretilen doğa" imgesini Central Park'ta kısa sürede oluşturmak için, parkın yapım aşamasında büyük ağaçların parka taşımasında özel araçlar yapılmış ve kullanılmıştır. Bu pastoral imgenin yapaylığını vurgulamak için Rem Koolhaas "junkspace" kelimesini kullanmaktadır. O'na göre “doğal elemanlar dizisi orjinal bağlamlarından alınmış, yeniden inşa edilmiş, bir gezintinin planlanmış informalliğinden daha formel olmayan bir alışveriş merkezinin dikdörtgenliğine sahip bir doğa sisteminin içine sıkıştırılmışlar".Bkz. Rem Koolhaas (1978), Delirious New York: a retroactive manifesto for Manhattan, Thames \& Hudson, London.

${ }^{6}$ Biyolog L. Hall, Olmsted'in park tasarımlarını, içerdiği sosyal hedefler, demokratik ve eşit erişim gibi sebeplerle antroposantrik (insan merkezci) olarak değerlendirmektedir. Bkz. Hall, L. (1995). Olmsted's America: An "Unpractical" Man and His Vision of Civilization. Boston, MA: Bulfinch Press.
} 
kuramında bahsettiği gibi, kent yöneticileri, kentsel bir kaynağı kendi amaçlarına ve değerlerine göre yönlendirebilmektedirler (Pahl, 1975). Olmsted, kent yöneticileri ile birlikte, peyzajı Amerikan kamusunun gücünü göstermek için bir araç olarak değerlendirmektedir. Olmsted'in kentin antitezi olarak yaratmak istediği doğa parçası, heterotopya'dan uzaklaştıkça, ironik bir şekilde kentsel süreçlere hizmet etmektedir.

\section{Peyzaj: Kamusal ve Özel'in Arasında İnsan için Peyzaj}

1920'li yılların sonundan itibaren ekonomide yaşanan sorunlar ve 1929 'da patlak veren Büyük Buhran'ın etkisiyle kamu kaynaklı projelerde kısıtlamalar yaşanmaya başlanır. Bu durum, büyük/üst ölçekli projeleri ve kent ölçeğinde peyzaj planlama çalışmalarını sekteye uğratırken, 1800'lü yılların son döneminde peyzaj mimarlı̆̆ çalışmalarında yaşanan gelişmelerin yerini, daha küçük/alt ölçekte ve özel sektör projeleri (konut, malikane, çiftlik evi gibi) alır ve bütün bu gelişmeler meslek disiplininin daralmasına neden olur. 1930'larda Harvard Tasarım Okulu Peyzaj Mimarlığı öğrencileri Garrett Eckbo, Dan Kiley ve James Rose, Büyük Buhran'a yanıt olarak, peyzaj tasarımında, farklı ekonomik sınıflara hitap eden ve peyzajın geniş çevrelere ulaşmasını öngördükleri demokratikleşme ruhunu savunmaktadırlar (Yiğit, 2004). Eckbo, Kiley ve Rose, Olmsted'in yaklaşımlarını politik amaçlara yönelik özel mekânlar üretilmesine aracılık ettiği suçlaması ile eleştirirler. Eckbo, "insanlar hacimlerde yaşar, düzlemlerde değil" iddiası ile Olmsted'in, peyzajı manzara olarak tanımlayan yaklaşımını eleştirir (Treib, 1993). Yaşam İçin Peyzaj [Landscape for Living] (1950) isimli kitabında, doğadan esinlenmek yerine, bilim ve teknoloji yoluyla bugünün yaşamsal ihtiyaçlarının karşılanmasını önerir (Rogers, 2001). Rose, peyzaj tasarımının, doğayı kendi haline bırakmak ya da onu taklit etmek yerine insan tarafından kolay algılanır olması için biçimlendirilmesi gerektiğini savunur (Yiğit, 2004). Bu sebeple üçlü, peyzaj tasarımlarında, daha rijid formlar, dikdörtgen formlar, V. Kandinsky ve Laszlo Moholy-Nagy'nin kübist ve surrealist biçimsel esinlenmeleri tercih ederler.

O dönem, Harvard Tasarım Okulu'nda, bölüm başkanı mimar Walter Gropius'un modern mimarlık yaklaşımı hakimdir. Eckbo, Kiley ve Rose, Gropius'un Bauhaus müfredatını uyguladığı, modern mimarlık anlayışından ve dönemin modern mimarlık ikonu olan Mies van der Rohe'nin Barcelona Pavyonu'nun tasarım prensiplerinden etkilenirler. Harvard Üniversitesi'nde ayrı ayrı bölümler olan mimarlık, peyzaj mimarlı̆̆ı ve planlama okullarının, 1936 yılında Tasarım Lisansüstü eğitim-öğretimi altında birleştiril- 
mesiyle birlikte, disiplinler arası etkileşimleri artar (Mumford, 2009). Eckbo, Kiley ve Rose, mimarlık alanındaki gibi, peyzaj mimarlığına modern ve insan temelli bir yaklaşım getirilmesi gerektiğini savunmaktadırlar. Üçlü, peyzajı, doğa ile ilişkilendirerek tanımlamak yerine, insanın gelişimine hizmet edecek sosyal bir araç olarak tanımlamayı tercih ederler. Gropius'un söylemlerinin etkisiyle, peyzaj, doğa, manzara ve görsel sanat faktöründen ziyade, tasarımda insan faktörünü ön plana çıkarmaktadırlar. Eckbo, Kiley, ve Rose, aynı zamanda, dönemin modern mimarlık manifestolarını andıran bir manifesto yayınlarlar. Tüm iki boyutlu, tarihsel, neoklasik ve natüralistik stilleri, aksı ve simetriyi reddeden, desen yerine hacimlere yönelen, her türlü sosyal gruba hitap eden, bitkilerin bilimsel kullanımına odaklanan, mimarlık ve dış mekanın entegre edilmesini vurgulayan tasarım yaklaşımları önerirler (Treib, 1993).

Her ne kadar, Eckbo, Kiley ve Rose peyzajın sosyal boyutunu değerlendirmekte ve kentteki tüm sınıfların peyzaja eşit erişimini savunsalar dahi, kuramsal üretimlerinden farklı olarak kamu yatırımlarının ve üst ölçek projelerinin azlı̆̆ı sebebiyle peyzajın kent ile kuracağı ilişkiye dair pratikleri eksik bırakılmak durumunda kalmıştır. İçinde bulundukları dönemin koşulları ile bağlantılı olarak, büyük oranda, 1950'lerin Amerikan kentlerinde hüküm süren, banliyöde refah içinde yaşam hayallerini destekleyen özel bahçe tasarımları ${ }^{7}$ yaptıklarını söylemek mümkündür. Pratikte peyzaj, yeni kentsel gelişme alanlarında dönemin Amerikan ekonomisinin tetikleyicisi olan kütle tüketimini (Cohen, 2004) pazarlayan bir öge haline gelmiştir.

1960'larda avantgard mimarlığa ve modern planlama anlayışına karşı artan eleştiriler, peyzaj mimarlığında insan faktörünü ön plana alan yaklaşımı sekteye uğratır. Eckbo, Kiley ve Rose'un kentsel süreçler içerisine entegre olamayan modern peyzaj yaklaşımı, sadece biçimsel bir tavır olarak kalmıştır. 1953 yılında, Lluis Sert Harvard Tasarım Fakültesi'nde bir dersinde, mevcut kent merkezlerinde bütüncül çevre yapılandırmasını ifade etmek için kentsel tasarım [urban design] terimini kullanır (Mumford, 2009). 1956 yılında, Lluis Sert önderliğinde Harvard Üniversitesinde düzenlenen bir

\footnotetext{
${ }^{7}$ G.Eckbo'nun Laurel Kanyonu, Los Angeles, (1954), Burden bahçesi (1945), Fisk Bahçesi, Atherton, (1939), Taub Bahçesi, Los Angeles (1957). Shulman Evi. Los Angeles (1951), Goldin Bahçesi, Los Angeles (1950lilerin ortaları), Harryman Bahçesi Los Angeles (1950lilerin ortaları), Chappell Bahçesi, Bel Air (1950lilerin ortaları), Reiner Bahçesi, Los Angeles (1956), Cranston Bahçesi, Los Angeles (1950'ler), Cole Bahçesi, Beverly Hills, (1950’lerin başı), Rich Bahçesi, Los Angeles (1950lilerin ortaları), Goetz Bahçesi, Holmby Hills (1948), Alcoa Bahçesi (1959), Sudarsky Bahçesi Bakersfield, (1959). Reid garden, Palo Alto (1940), J. Rose'un konut bahçesi (1954), D. Kiley'in Miller bahçesi (1955) yaptıkları özel konut bahçe tasarımlarıdır.
} 
konferans ile kentsel tasarım çalışma alanı tanıtılır ve ardından Harvard ve Pennsylvania Üniversitelerinde yüksek lisans eğitim programları açlır (Mumford, 2009, s.120). Böylece, peyzaj tasarımının kentsel süreçler ile ilişki kurma olasılıkları, kentsel tasarım yaklaşımı içerisinde tartışılmaya başlanır. Peyzajı, mimarlık ve insan üzerinden tanımlamanın beraberinde getireceğ $\mathrm{i}$ olasılıklar, o dönem için peyzaj mimarlığı disiplininin içerisinde çeşitlenemeden kaybolur.

\section{Peyzaj: Doğayı Anlamanın Bilimi, Kenti Planlamanın Yol Göstericisi}

1960'lara kadar, peyzaj kuramında yaygın olarak peyzajı manzara olarak gören Olmsted'in tavrı hakimdir. Ancak 1960'lar çevre problemlerinin görünür olmaya başladığı, modern ve totaliter mimarlık yaklaşımlarına karşı eleştirilerin arttı̆̆1 bir dönemdir. Bu dönemde, Pensilvanya Üniversitesi'nden kent plancisı ve peyzaj mimarı Ian McHarg, hem doğanın korunarak, hem de kentin gelişmesinin devam ettiği bir yöntem ortaya koyar. McHarg, doğa ve kent'i birbirine zıt olarak tanımlamak yerine, doğayı ve kenti bir arada yeniden değerlendirir. McHarg'a (1969, s. 5) göre, “doğa, kırsalda olduğu kadar kentte de vardır. bu kent ya da kırsal arasında bir seçim yapmak değildir; ikisi de gereklidir....ancak bugün, kentteki doğa kuşatıldığ1 ve azaldığı için kıymetlidir".

McHarg'ın (1969, s.74) "insan doğada var olur ama bireyin eşsizliğini tanımak önemlidir" ifadesinin, hem doğaya hem insana değer verdiği söylenebilir. Ancak Olmsted'ten farklı olarak peyzaja atfettiği rol, mistik ve bilinmez değil; gerçekleri bilim yoluyla keşfedilebilen, analiz edilebilir, gizemi çözülebilen bir ilişkiler bütünüdür. McHarg, 1954-84 yılları arasında Pensilvanya Üniversitesi'nde Peyzaj Mimarlığı Bölümü'nün eğitim programını ekoloji üzerinden şekillendirir. Öğrencisi Spirn'in ifadesi ile, McHarg, neden olarak ekoloji'ye [ecology as cause] inanmaktadır (Spirn, 2000) ve doğayı bir süreç olarak anlamaya, neden ve nasıl var olduğunu çözümlemeye çaba göstermektedir. O'na göre, doğada bir peyzaj karakterinin, belli bir noktada olmasının bir sebebi vardır ve bu neden-sonuç ilişkisi, bilim yoluyla anlaşılabilirdir (McHarg, 2006; Spirn, 2000). Bu doğrultuda McHarg, peyzaj kelimesini doğa kelimesiyle eşleştirmek yerine, ekoloji kelimesiyle eşleştirir. McHarg'ın peyzaja yaklaşım biçimi de, ekoloji biliminin akılcı yöntemleriyle onun gizemini çözümlemeye yöneliktir. McHarg'a göre ekoloji, sadece nedenleri anlamamıza değil, kentlerin olumsuz koşullarını tedavi edilebilecek tasarımın nasıl yapılacağına da ışık tutmaktadır (Beilin, 2013; Herrington, 2010). McHarg'ın 1969 yılında yayınladığı, büyük yankı uyandıran Design 
with Nature [Doğa ile Tasarlamak] (1969) kitabında anlattığı ekolojik planlama yöntemi, kentlerin ekolojik bir şekilde, "doğa ile tasarlanması" gerektiği üzerine kuruludur. Bu sebeple, McHarg, koruma planlamasının da öncüllerinden olarak atfedilir" ${ }^{8}$ 1960'lar boyunca McHarg, Amerikan ulusal çevre politikalarının belirlenmesinde önemli rol oynar. Bu noktada, kenti, doğa aracılığı ile tedavi edilecek bir araç olarak tanımlaması Olmsted'in yaklaşımına benzerlik gösterse dahi, peyzaja atfettiği rol farklıdır. McHarg, ekolojik planlamanın sadece yeşil alanlar ya da parklar için değil, tüm kent ve tüm arazi kullanımları için uygulanabilir olduğuna inanmaktadır ${ }^{9}$. Olmsted'in kenti tedavi eden pitoresk parkları, estetik aracllığı ile bir iyileşme öngörürken, McHarg'a göre, tasarım ve planlamada estetik ekolojiden gelmelidir (Spirn, 2000, s.112).

McHarg, doğayı ve kenti birbiri ile ilişkili ama iki farklı biçim olarak tanımlar. Doğa, yaratılandır, vahşidir, yaratılan biçimdir [given form]. Kent ise, doğanın insan tarafından değiştirilmiş hali değiştirilen biçimdir [made form]. McHarg tasarımı, "yaratılan biçimin derinlemesine kavranması" ve "değiştirilen biçim için önerilerde bulunma" olarak tanımlar (McHarg, 2006, s. 43). McHarg, insan-doğa arasındaki, yaratılan ve değiştirilen biçim arasındaki "potansiyel uyuma" inanmaktadır (McHarg 1969, s. 5). Bu sebeple, McHarg, belli bir arazinin çevresiyle en uyumlu arazi kullanımını çözümlemek için, Charles Darwin'in Türlerin Kökeni (1859) ve Lawrence Henderson'ın Çeoreye Uyum (1913) adlı kitaplarından esinlendiği, peyzajı, çevresiyle en ideal uyumu yakalayana kadar istila eden, evrilen, değişime uğrayan, çevresiyle en iyi uyumu sağladığında durağan hale gelen bir sistem olarak yorumladığı yaratıcı uyum [creative fitting] teorisi üzerinden bir planlama perspektifi geliştirir. Bu noktada, Park, Burgess, Mckenzie ve Wirth'in temsil ettiği, kentin mekânsal örgütlenme biçimini kuramsallaştıran, 1920'lerin baskın ekolü olan Chicago Ekolü'nün bakış açısı ile ve özellikle de Park'ın kenti, rekabet, istila ve hâkimiyet, uyum ve denge süreçleri sonucunda dengeye kavuşacak bir ekosistem olarak ele alma eğilimi ile benzerlik göster-

\footnotetext{
${ }^{8}$ Ian McHarg'a göre peyzaj mimarlığı, "insanın dünyasında doğanın önemine inanan, yaşamın, doğa ile tasarlanması gerektiğine inanan insanların meslek alanı"dır. McHarg, profesyonel alan dışında da, insanlarda çevre bilincinin yaygınlaşmasını sağlamak için Amerikan radyosunda Insan ve Çevre [Human and Environment] isimli bir radyo programı program yapar. Bkz. McHarg, I. (1969) Design with Nature. New York: Natural History Press, s.2.

${ }^{9}$ McHarg'ın kuramsal yaklaşımı, 1960'larda hayli yaygın bir kuram olan, tüm çevresel elemanların ağlar şeklinde birbirlerine bağlı olduğunu savunan, sistem teorisinden etkilenmektedir (Spirn, 2000). Bu sebeple, kent içerisindeki peyzajı ve parkları, kent mekanlarından ayrı değerlendirmemektedir.
} 
mektedir. McHarg, plansız insan yerleşimlerine karşı çıkarak, tüm sektörlerde çevre ve insan arasında en uyumlu ve stabil durumu planlamayı, doğa ile tasarlamak olarak tanımlamaktadır.

McHarg, Patrick Geddes'in coğrafya bilimine dayanan yöntemlerini model alarak araziyi, iklim, jeoloji, fizyografi, hidroloji, toprak, vejetasyon, yaban hayatı gibi tematik katmanlara ayırır, insan ve doğa arasında uyumlu bir yaşam oluşturmak için, araziyi analiz eder ve doğanın sistemini bozmayacak ekolojik bir arazi kullanımı planlaması yapar. Ortağı Davis Wallace ile "Vadiler Planı, Kontrol Edilemeyen Büyüme Hayaline Karşı" [Plan for the Valleys vs. Spectre of Uncontrolled Growth] (1965) isimli vadiler üzerine ürettikleri proje ve metinleri kapsayan makalesinde, vadilerde jeoloji, topoğrafya, ekonomi gibi birçok ögeyi katman katman analiz ederler ve planlı büyümenin ekonomik olarak nasıl daha karlı olduğunu ortaya koyar. Bu sayede, McHarg'ın geliştirdiği güçlü yöntem, kuramının önüne geçer. Planın yapılmasında aktif rol oynayan bu bölgede yaşayacak varlıklı kişilerin talebi, planın arazinin manzarasını bozmadan, çevresel kalitesini azaltmadan bir plan yapmasıdır (Spirn, 2000, s.103). 1970'lerin başlarından itibaren işverenleri, yeni gelişim alanları ve tatil bölgeleri geliştiren özel girişimci ve yatırımcılar oluverir. McHarg birçok yeni gelişme alanının planını yapar. 1973'teki petrol ambargosu ve 1975'teki petrol fiyatlarındaki ani artışın Amerikan ekonomisini yavaşlatması sebebiyle Orta Doğu ülkelerine de planlar yapmaya başlar. Her ne kadar, peyzaj mimarlığı disiplinini çevreci bir yaklaşım ile buluştursa dahi, peyzaj üzerinde yeni yerleşim alanlarının açılmasının karlı ve yasal yolunu yatırımcılara gösterdiği için aynı zamanda eleştirilir (Spirn, 2000).

McHarg'ın peyzaj planlama yaklaşımı, kentsel planlamada da en çok kullanılan araçlardan biri olmuştur. Görünürde, peyzaj, kentsel süreçlerce kabul edilmekte ve hatta onu yönlendirmektedir. Ancak, görünen odur ki, McHarg'ın analitik yöntemi, peyzajın, kentsel gelişme süreçlerinin tetikleyicisi olarak çalıştığı bir sonuca evrilmiştir. Harvey Molotch'ın (1976) iddia ettiği gibi, kentsel büyümenin yol açtı̆̆ ekonomik fayda, tüm kentlerin itici gücüdür ve kentin önde gelen aktörlerince desteklenmektedir. McHarg'ın tedavi edecek bir araç olarak tanımladığı peyzaj, bilim ve analitik çözümlemeler, kentin ekonomisi için itici güç oluvermişlerdir. Peyzaj, yine kentsel süreçlerden gücünü almaktadır ve hatta kentsel yayılımı meşrulaştırmaktadır. 


\section{Peyzaj: Kente Yön Veren Bir Süreç}

McHarg'ın öncülük yaptığı süreçte, peyzaj kent ve kentsel planlama tarafından kentin aktif bir katmanı olarak görülmeye ve kabul edilmeye başlanır. 1980 sonrası hem kentsel sistemler, hem de düşünce sisteminde radikal değişimler yaşanır. 1980'lerden sonra ekonomik aktivitelerin yerel, metropolitan, ulusal ve küresel ölçekte yayılmasının; bilginin, ulaşımın, iletişim araçlarının hızlarının ve erişimlerinin artmasının etkileri (Sassen, 2005), kentin ve mekânın artikülasyonunda da yeni arayışlara yol açar (Lyster, 2006).

1980 sonrası dünya düşünce sisteminde yer edinmeye başlayan post yapısalcı çözülme sonucu, doğa ve kent gibi zıt kavramlar birbiri içerisine geçmeye başlar. Çünkü antroposen çağında tüm doğa yeniden üretilmiş, çalışılmıştır. Kültürel coğrafyacıların ağırlıkta olduğu bir grup kuramcı, peyzajı kültürel bir üretim olarak tanımlarlar (Cronon, 1996; Gissen, 2009; Jackson, 1984; Meinig, 1979). Bu felsefi değişimle birlikte, peyzaj mimarlığında, doğayı, kültürün zıddı, ya da peyzajı kentin zıddı olarak gören algı yıkılmaya başlar. Kent, peyzajın içine, peyzaj da, kentin içine karışmıştır ve bu melez durumda, kentin, kendi doğası, kendi ekolojisi vardır (Corner, 1999, 2006; Spirn, 1984, 2000). 1980'lerin sonundan itibaren, çağdaş peyzaj mimarlığı kuramcıları (Corner, 1999, 2006; Hunt, 1992; Meyer, 1997; Spirn, 1984; Waldheim, 2002, 2010), peyzaj1, çağdaş kentsel yerleşimlerde doğa ve kültürle birlikte çalışan melez bir sistem olarak yorumladıkları yazılar yazarlar. Elizabeth Meyer, geç yirminci yüzyılı "zıtlıklar arasındaki gri alanın, melezlerin mekânlarının, ilişkilerin ve gerilimlerin keşfedildiği ve peyzajın da bu ara alanda yer aldığı" bir dönem olarak tarifler (Meyer, 1997, s.51). 1988 yılında, Paris'de düzenlenen Park de la Villette Yarışma Projesi'nin ödül alan projeleri, Olmsted'in, sanayi kentleri için ürettiği kent içindeki park [city in the park] yaklaşımından, yirminci yüzyıl kentinde kültürel bir alan olarak park [park as a space for culture] yaklaşımına evrilmesinin göstergeleridir. Bernard Tschumi'nin kentsel aktivitelerin karmaşık düzenini organize edecek en uygun araç olarak tanımladığı birincilik ödülünü alan projesi ${ }^{10}$,

\footnotetext{
${ }^{10}$ Park de la Villette Yarışması'nın (1982) birincilik ödülünü alan Bernard Tschumi, parkı kültürel bir olgu olarak değerlendirir. Tschumi, katı planlar üretmek yerine, arazi üzerinde olayların gerçekleşmesine olanak verecek koşulları sağlayan bir mimari program önerir. Tschumi, program ve olay arasındaki farkı şöyle açıklar: "program, tekrar ve alışkanlığa bağlıyken daha öngörülebilirdir; ancak bir olay önceden kestirilemez, rastgele meydana gelen ve tasarlanamaz". Tshumi, mimari programı araziye dağıtırken Folies olarak adlandırdığı kesin bir işleve sahip olmayan ama çeşitli program olasılıkları barındıran objeler tasarlar. Park boyunca tekrar eden Folies ve işlevleri, parktaki yaşam tarafından belirlenecektir. Bunun yanında parktaki bazı
} 
peyzajı1, zaman içerisinde programı ve politiği değişen bir olgu olarak ele alması, çağdaş kentleşme ve peyzaj ilişkisinin yorumlanmasında bir paradigma değişimine işaret etmektedir (Waldheim, 2002).

1990'larda, peyzaj kuramında, doğa-kültür sentezinden doğan bir paradigma değişimi yaşanır. 1997'de Detroit'de, Charles Waldheim ve James Corner öncülüğünde bir dizi konferansta peyzaj mimarlığı disiplininin s1nırları tartışılır ve peyzajın, kentlerin bir parçası olmanın ötesinde, kentsel süreçlerde aktif rol oynadığı kentleşme modeli olarak peyzaj kentleşmesi [landscape urbanism] yaklaşımı tanıtılır ${ }^{11}$. Karşısında durduğu, kompakt, yaya-dostu, ve "kuram dışı" 12 yasal yönetsel öneriler, bina kodları, standartlar aracılığ 1 ile kentin gelişimini kontrol etmeye çalışan Yeni Kentleşme Hareketi'ne [New Urbanism] eleştiri olarak, peyzaj kentleşmesi, yüklü bir kuramsal metne dayanmaktadır (Duany ve Talen, 2013). Peyzaj kentleşmesi, geleneksel kentleşmenin peyzajı, sadece kentin bir katmanı olarak görmesini, kentsel tasarımin geleneksel kentsel formlara olan nostaljik ilgisini ve Yeni Kentleşme'nin, ekoloji ve sürdürülebilirlik ile kurduğu tek ilişkinin kentin boşlukları doldurarak kompakt bir kentsel form aracıllğı ile enerji tasarrufu sağlamak olmasını eleştirmektedir (Waldheim, 2010, s. 24). Corner'a (2006, s. 27) göre, hem mimarlık, hem de planlama, peyzajı, kent formuna entegre etmekte başarısız olmuşlardır. Bu yeni model, postmodern kentleşmede, peyzajın yatayda yayılan karakterinin, değişken, dinamik, çok katmanlı ve hiyerarşik olmayan yapısının kenti yönlendirdiği bir modeldir (Waldheim, 2002). Waldheim, peyzaj ve kent kavramlarını bir arada kullanarak, o güne kadar peyzaj mimarlı̆̆ disiplini içerisinde en yaygın anlayış olan doğa ve kent arasındaki zıtlı kodlamayı kırmaktadır (Weller, 2014, s.93).

Peyzaj kentleşmesi, geleneksel peyzaj anlayışındaki gibi peyzajı pasif bir olgu, bir manzara ya da bir katman olarak tanımlamak yerine, yaşayan,

bölgeler, sıkıştırılmış toprak ve çakıl yüzeyler olarak program olarak özgürlük sağlayacak şekilde boş bırakılmıştır. Bkz. Miljacki, A., Lawrence, A. R. ve Schafer, A. (2006). 2 Architects 10 Questions on Program: Rem Koolhaas+Bernard Tschumi, Praxis 8. Erişim adresi: http://www.anamiljacki.com/wp-content/content/Article_Praxis8.pdf.

${ }^{11}$ Konferanstaki konuşmacılar, I. McHarg, J. Corner, M. Mostafavi, L. Pollak, B. Shim, A. Geuze, A. Wall, J. Roig, G. Jones ve K. Poole, peyzajı, kentleşmeyi yönlendirici bir aktör olarak tanımlamışlardır.

${ }^{12}$ Andrés Duany ve Emily Talen, Yeni Kentleşme'nin kentsel tasarımın kuramsal gündeminden uzak olduğu için "kuram-dışı" olarak nitelendirmektedirler. Bkz. Duany, A. ve Talen, E. (2013). Looking Backward: Notes on a Cultural Episode. A. Duany and E. Talen (Ed.), Landscape Urbanism and its Discontents: Dissimulating the Sustainable City (s.1-16) içinde. New Society Publishers. 
işleyen, çalışan bir sistem olarak ele almaktadır. James Corner, peyzaj kavramının kültürle olan ilişkisini dikkate alarak, peyzajın çok boyutlu ve melez yapısının yeniden tanımlanmasının gerekliliğini vurgular:

“ölçeğinin ve kapsamının büyüklügünden ötürü, peyzaj, çok katmanlı ve çoğulculuğu kapsayacak bir metafor olarak hizmet etmektedir. ...bu terminolojiyle doğaya özgü ve fenomenolojik deneyimleri kucaklayabilir......peyzaj, çeşitli ve birbiri ile çelişen güçleri (sosyal yapılar, politik arzular, ekolojik süreçler program talepleri gibi) yeni özgürleştirici ve etkileşimli işbirliklerine doğru düzene sokar" (Corner, 1999, s. 2-3).

James Corner, salt doğal dünyanın çevreciliğinin peyzajı, pasif ve sadece korunan bir olgu olarak ele almasını eleştirmekte, insan ile ilişkisinde, çok daha aktif bir rol atfetmektedir. Peyzaj, ne kentin zittı, ne onu tedavi edecek bir manzara, ne de korunması gereken bir kaynaktır. Bu noktada, Corner, peyzajı, bir "isim" (bir obje ya da manzara olarak) olmanin ötesinde, süreç ya da aktivite; yani bir yüklem olarak nitelendirmektedir (Corner, 1999, s. 4). Peyzaj, kentsel ögeleri, bölgesel ve biyotik bağlamlarıla ilişkilendirerek, dinamik çevresel süreçler ile kentsel form arasındaki ilişkileri şekillendiren bir aktördür13 (Corner, 2006); sadece kültürün bir yansıması değil; "modern kültürün şekillenmesinde rolü olan aktif bir araçtır"(Corner, 1999, s. 1). Corner, peyzajin değişken ve dinamik karakterinin kenti zaman içerisinde şekillendirmesini öngörmektedir. Corner'ın Fresh Kills Park (2001) ${ }^{14}$ için yaptığı tasarımda peyzajın araziyi biçimlendirici etkisi, kendi formundan çok daha önemlidir: “... arazi yeni bir tür kamusal-ekolojik peyzaj potansiyeli sunmaktadır, insan yaratıcilığına biyolojiden beslenen, mekan ve form yerine zaman ve süreç tarafından yönetilen yeni bir paradigma, sunmaktadır" (Field Operations 2002, 7).

\footnotetext{
${ }^{13}$ Corner'ın peyzajı, bir aktör olarak tanımlanması, ekosistemleri, değişen çevre koşullarına uyum sağlayan, kendi kendini organize eden, sürekli evrilen, açık bir sistem olarak görmesi, açık ekosistem yaklaşımı'nın uzantısıdır. Açık ekosistem anlayışı, ekolog C.S. Holling' in "ekosistem gelişiminin dinamik döngüsü" teorisinden yola çıkarak, ekosistemleri, kapalı, hiyerarşik, doğrusal gelişim gösteren sistemler olarak tanımlamak yerine, dinamik, karmaşık, kendi kendini organize eden, düzenli ritimlerle değişen ve bir dereceye kadar tahmin edilemez açık sistemler olarak tanımlamaktadır. Bkz Holling, C. S. (1986). Resilience of ecosystems; local surprise and global change. W. C. Clark ve R. E. Munn (Ed.), Sustainable Development of the Biosphere (s. 292-317) içinde. Cambridge: Cambridge University Press.

${ }^{14}$ Fresh Kills Park, New York, Staten Island'da 890 hektarlık bir dolgu alanıdır. James Corner ve Stan Allen, bu dolgu alanının otuz yıl içerisinde bir parka dönüştürülmesini "hem bir yer hem de bir süreç" olarak kurgularlar. Park, statik bir sonuç form veya estetik bir kategoriden ziyade sürecin bir yan ürünüdür.

Bkz. Field Operations, “Fresh Kills Park: Lifescape”, Draft Master Plan, March 2006.
} 
Bütün bu gelişmeler doğrultusunda, Kaplan (2020)'nin de belirttiği gibi günümüzde peyzaj artık tek boyutlu, kapalı, statik ve pasif konvansiyonel tanımlarından sıyrılmış, çok boyutlu, açık uçlu, dinamik, değişken, aktif, kültürel normlar üreten bir olgu olarak tanımlanma biçimleri kazanmıştır. Corner'ın tanımlama biçiminde peyzaj, tüm araziyi şekillendiren performatif bir rol kazanır ve operasyonel bir araca dönüşür (Bingöl, 2020). Operasyonel bir araç olarak peyzajın yönlendirdiği süreç, insan aktivitesini ve peyzaj sistemlerini daha esnek, değişken, adapte olabilen yaklaşımlar ile yöneten ve bu sürece dair stratejiler üreten (Corner, 1999) süreç odaklı tasarımları beraberinde getirmektedir. Bu durum ayn zamanda, yirmi birinci yüzyılın dinamik, değişken ve belirsiz kentlerine uyum sağlamanın da bir yoludur. 2000 yılında Toronto'da eski bir askeri üssün park alanına dönüşümünü içeren Downsview Parkı Projesi Yarışma ilanı, alanı kültürel bir kentsel alan olarak değerlendirmenin yanında, yarışmacılardan "ekosistem koşullarındaki ve insan kullanımındaki zaman içerisindeki değişimi dikkate alan tasarımlar geliştirmelerini" beklemesiyle süreç odaklı bir yaklaşıma doğru değişimi işaret etmektedir (Hill, 2001, s. 95). Yarışma projeleri, bitmiş biçim yerine, dinamik ve uyum sağlayan süreçlerin, açık ve akışkan sistemlerin ve tasarımdan çok stratejilerin kurgulanmasına yönelik çözümler geliştirmişlerdir (Van Alen Institute, 2000) .

Kamusal alanların kültürel kapitalizm ve neo liberal süreçler ile kaçınılmaz ilişkisi, bir şekilde peyzajı yine kentsel dinamikler ile çarpıştırmaktadır. Downsview Park Yarışma Projesi'nin Rem Koolhaas ve Bruce Mau tarafından birincilik ödülünü alan projesi Tree City, peyzajın dönüşerek stratejik bir şekilde araziyi şekillendirmesini süreç-temeli ele alarak birden çok plan şeması ile ortaya koymaktadır. Ancak 1980 sonrası kentsel yenileme projeleri, sadece kamu eliyle yapılmak yerine, șirket ve devlet güçlerinin ve pratiklerinin yeni bileșimleritarafından yönlendirilmektedir (Smith, 2006). Downsview Park Incorporated (PDP), Crown Corporation, Tree City Inc.gibi kamu, tüzel ve özel kişilerden oluşan kuruluşlar tarafından yönetilen Downsview Park'ın inşaa süreci, projenin danışmanlarının ve paydaşlarının fazlalığından ötürü gecikmeli olarak yürütülmüştür (North, 2012). Parkın inşaasının yavaş olmasından ötürü, arazi fiyatlarında arttırması öngürülen rantı sağlayamaması ve projenin raporunda öngörülen "kendi kendini finanse etmesi"nin (Hill, 2001) sağlanamamasından dolayı projenin temel kurgusunda önemli değişiklikler yapılmıştır. Nihayetinde, proje, uygulama aşamasında statik ve tek bir plan şemasına sahip bir master plana indirgenmiştir (North, 2012). Süreç temelli projelerin uzun zaman isteyen 
uygulama aşaması, kentin hızlı ve rant beklentisi içinde olan dinamikleri karşısında duramamıştır.

Peyzaj kentleşmesi, birebir banliyö kenti ya da yayılan kent önerisinde bulunmamakta ancak, akımın öncüleri, kompakt kentleşmeye karşı çıkmaktadırlar. Peyzajın yayılan formunu, kent için bir model olarak önerirler. Kentsel boşluklar, kent içerisinde alternatif ve beklenmedik kamusal alanlar sundukları için birer potansiyeldirler (Mostafavi, 2003). Böylece, belirgin olarak peyzaj kentleşmesi kategorisi altında anılmasa da sıklıkla postmodern kentlerin post endüstriyel boşluklarında süreç-odaklı dönüşüm projeleri olarak karşımıza çıkmaktadır. Eski fabrika yapıları, eski maden ocakları, çöplük alanları gibi kentin içerisinden endüstriyel dönemden kalan işlevini yitirmiş boşluklar, yeni işlevler kazandırılarak kamusal alanlara dönüştürülmektedir. Ayrıca, kentsel altyapının, kentin dışına taşan kilometrelerce uzayan geniş boşlukları da geliştirilmeye açık peyzaj alanları olarak tanımlanır. Peyzaj, sadece doğal sistemler ya da yeşil alanları değil, yoğun kentsel merkezler, kentin dışına doğru yayılan banliyöler ve onları birbirine bağlayan geniş altyapıları ve altyapı ağları da peyzajın ögeleridir (Meyboom, 2009). Strang'in (1996) peyzaj altyapilar [landscape infrastructure] olarak adlandırdığı, metrelerce mesafelerde uzanan depolar, çöp alanları, yollar, dönüştürücüler ve zeminin altındaki ağlar, birbirine bağlanan erişim alanları, daha önce tanımsız bir şekilde uzanırlarken, artık somutlaştırılarak peyzaj alanlarına dâhil oluverirler. Bu noktada, 1990'larda Amerika'da kentleşme süreçlerinin, tıpkı II. Dünya Savaşı sonrasında olduğu gibi, büyük oranda banliyöleşme ve kentsel yayılım üzerinden devam ettiğini hatırlamakta fayda vardır (Glaeser ve Shapiro, 2001). Kentin çeperi, kentleşmenin yanında geniş potansiyel boşlukları içermektedir. Strang'e göre (1996), bu ortak zemin, doğal ve insan sistemleri arasında estetik, fonksiyonel, sosyal ve ekolojik ilişkileri birbirine bağlamaktadır. Böylece, peyzaj, sadece kent içerisinde dönüştürülecek boşluğun çok ötesine geçmektedir ${ }^{15}$. Peyzaj, artık Olmsted'in tariflediği gibi sadece yeşil bir sistem değil, ulaşım altyapısı, mavi altyapıyı ve bugünün bilgi altyapısı, program altyapısı, kültürel altyapı, sanal altyapı gibi yeni yumuşak altyapıların da bir parçasıdır (Kwinter, 2008). Biyolojik/ekolojik ağlar (hidroloji, jeoloji, biyokütle, iklim), kentsel ağ

\footnotetext{
${ }^{15}$ Bkz. Field Operations tarafından yapılan High Line, West 8 tarafından önerilen Leeuwarden By-Pass ve Eastern Scheldt Storm Surge Barrier, P.Belanger tarafından önerilen Energy Dike: Proposal for a Blue Energu Systam along the Afsluitdijk in the Netherlands, Weiss and Manfredi Architects tarafindan yaplan Olympic Sculptur Park, SWA Group tarafından önerilen Museum of Freeway Art, Landlab tarafından önerilen Cantabria Network of Coastal Pedestrian Paths, Projeleri peyzaj altyapıları düzenlemesi içeren bazı proje örnekleridir.
} 
sistemleri (enerji sistemleri, ulaşım sistemleri, atık ağları vs.) bir arada değerlendirilmektedir (Belanger, 2012). Meyboom'a (2009) göre, bir altyap1 olarak peyzaj, hem üst ölçekte kamusal birleştiriciliği ve hem de insan ölçeğinde farklı deneyimler sunma rolünü üstlenerek birden çok ölçekle entegre olmuş tasarım olasılıkları sunmaktadır. Farhat'a göre (2008), altyapının sabit statik yapısının üzerine peyzajın esnek ve değişken yapısını entegre etmek, kentsel formun, esnek ve değişime adapte olabilecek planlanma olasılıklarını ortaya çıkarmaktadır. Gerçekte olan ise, enerjinin ve kaynakların üst ölçekteki akışının ve bunların ağ mekânlarının, tanımsız alan olmaktan çıkarılması ve tasarıma kazandırılmasıdır. Bütün bu kavramsallaştırmalar, peyzajın tekil, stabil ve lokal olarak değerlendirilmesinin ötesine geçip, "bölgesel ölçekte bir iletişim ağı" olarak ele alınmasının bir göstergesidir (Kaplan, 2020, s.26). Gerek peyzaj kentleşmesi yaklaşımı, gerek de peyzaj1 bir altyapı olarak değerlendiren anlayış, peyzaja dinamik bir rol atfederken (Kaplan, 2020), kent mekânındaki endüstriyel dönemden kalma işlevsiz alanlarına ve kentlerin arasındaki geniş altyapı boşluklarına neo-liberal doktrinin ve süreçlerin girmesi ve müdahalesi için bir araç olmaktadır. Günümüzün küresel dünyasının pazarlanan kentlerinde, peyzaj, kültürel tüketimi aktive edecek, kenti turistler için çekici bir destinasyon haline getirecek, kentin bir marka olmasına aracllık edecek ögeler oluvermektedirler. James Corner'ın, eski bir demiryolu hattını bir park alanına dönüştürdüğü High Line Projesi'nin 2009'daki açllış töreninde, New York kentinin belediye başkanı Michael Bloomberg, yeni park alanının, "kentin geleceği için sıradışı bir hediye" olduğunu vurgulamaktadır (Loughran, 2014, s.1). Proje, "Halo Effet/ Hale Etkisi" olarak adlandırılan, kent içerisinde kalan eski endüstriyel bölgenin arazi fiyatlarının radikal bir şekilde artmasına ve bölgenin soylulaştırılması için bir araç oluvermiştir (Quintana, 2016). 1950, 60 ve 70’lerdeki kamu eliyle yapılan kentsel yenileme çalışmaları kentin ekonomisi için itici bir güç iken, 80 sonrası șirket ve devlet güçlerinin ve pratiklerinin yeni bir bileșimi tarafından yönlendirilen yenileme projeleri, kentlerde belli bölgelerin arazi fiyatların, ve rantı arttırma amacına dönüşmüş ve soylulaştırmaya neden olmaktadır (Smith, 2006).

1990 sonrası peyzajın, özellikle yenileme bölgelerinde kentin yeni üretken ekonomisinin merkezi haline gelmesi tesadüfi değildir. 1999 yılında yayınlanan "İngiliz yenileme manifestosu, ilerleyen 25 yıl için kentin gelişimi ve konut üretimi için gerekli alanın \%60'ını terk edilmiş endüstri alanlarmda [brownfield] önermesi" (Smith, 2006, s.24), bu eski endüstri alanlarına inşaat faaliyetlerini çekmiştir. Smith'in (2006, s. 23) “üçüncü tür soylulaştır- 
ma" olarak ele aldığı, konut üretiminden yeni peyzaj yapılarının (yeni rekreasyon, tüketim, üretim ve eğlence yapılarının) üretimine kayan kentsel yenileme, bu alanların kentin turizmini de destekleyecek şekilde pazarlanması ile kentin başat ekonomisi haline getirilmesi, peyzajı neo-liberal süreçlerle bütünleştirmekte ve peyzajın üretimindeki kamusal amacı çelişkili hale getirmektedir ${ }^{16} .1990$ sonrası üretilen birçok peyzaj projesi ${ }^{17}$, terkedilmiş endüstri bölgelerinde yer almakta, yenileme beraberinde soylulaştırmayı ve kentsel markalaşmayı getirmektedir. Böylece, kentler arasındaki mekânlar da dâhil olmak üzere insan elinin dokunmadığı boşluklar kalmamaktadır. Altyapı alanlarını, kendiliğindenlikten çıkarıp, bu alanlara tasarım müdahalesinin girmesi, üst ölçekte tüm heterotopyayı izotopyaya dönüştürmektedir. Her ne kadar peyzajin tanımı ve kapsamı kente yaklaşıyor gibi gözükse dahi, kentin değişen dinamikleri, peyzajın kentsel süreçlerle işbirliğini sürekli güncellemeye devam etmektedir.

\section{Tartışma ve Sonuç}

Peyzaj, sabit, statik bir kavram ya da imge değildir; içeriğini ve anlamını sürekli değiştiren muğlak bir kavramdır. Kaya'nın (2017) de vurguladığı gibi, peyzaj, tek başına çok farklı anlamlara sahip farklı yorumların soyut ifadesi olmakla birlikte mimarlık mesleği ile bir araya geldiğinde somut bir çalışma alanı tanımlamaktadır. Bu muğlak kavramın mekânsal pratiğiyle yakından ilgili olan peyzaj mimarlığı disiplininin mekânsal tipolojileri de yirminci yüzyılın başından beri, özel bahçelerden kamusal parklara, kent içerisindeki post endüstriyel alanlardan, altyapı alanlarına, rekreasyon alanlarından, eğlence mekanlarına kadar sızan pratiklerle çeşitlenmiştir.

Kurumsallaştığı yirminci yüzyılın başından itibaren, peyzaj mimarlı̆̆ disiplini içerisinde peyzaj kavramı sıklıkla, kentin ötekisi, Foucoult'un ifadesiyle heterotopya olarak tariflenmektedir. Görmüş'ün (2019) de ortaya koyduğu gibi kavramın, doğa ile çok çeşitli akrabalık kombinasyonları var-

\footnotetext{
${ }^{16}$ Kamusal alanların kültürel kapitalizm ve neo liberal süreçler ile ilişkisi için Bkz. Brenner 2004; Harvey 2002; Peck et al. 2009. Bunun yanında, High Line Projesinin, kent, kentleşme ve neo liberal süreçlerle ilişkisinin detaylı incelemsi için Bkz. Lougran, 2014.

${ }^{17}$ Eski endüstri alanlarının dönüşümüne dair Field Operations tarafından tasarlanan Fresh Kills Park (2000) ve High Line (2011), YIYU design tarafından tasarlanan Shanghai MOMA Museum Waterfront Park (2017), Latz + Partner tarafından tasarlanan Landschaftspark Duisburg Nord (2002), Planergruppe Oberhausen tarafından tasarlanan Zollverein Park(2017), Sasaki tarafından tasarlanan Xuhui Runway Park (2019), Planergruppe Oberhausen tarafından tasarlanan Zollverein Park(2017), Ramboll Studio Dreiseitl tarafından tasarlanan Zollhallen Plaza (2015), Jochiwon Cultural Garden, Ilex LA tarafindan tasarlanan Parc des Iles (2010), McGregor Coxall tarafından tasarlanan Ballast Point Park gibi sayısız örnek verilebilir.
} 
dır. Ancak, peyzaj kavramı, doğa ile eşleştirilerek tanımlanırken bile, bu yaklaşımın, nötr ve ilişkisiz bir anlayışı olduğu söylenemez. Peyzaj, kültürel bir inşaanın ürünüdür. Peyzaj kavramının tanımlanma biçimi ve peyzaja atfedilen rol, yaşanan dönemin yaşam ve üretim ilişkilerine, sosyal, politik, ekonomik ve fiziksel çevresine ve düşünce dünyasına bağlı olarak değişim göstermekte veya çeşitlenmektedir. Kavram, sanayi öncesi dönemde kırsal üretim, yaşam ve mekansal biçimler ile ilişkili bir terminoloji ile eşleştirilirken, sanayi devrimi sonrası kırsaldan kente evrilen yaşam içerisinde kentleşme ve sanayinin doğal ve kültürel kaynakları ve yaşam ortamlarını tahrip ya da yok etmesi sebebiyle sanayi kentlerinin sağlıksız yaşam koşullarına karşıt bahçe, park, orman, göl gibi açik-yeşil ortamlarla eşleştirilerek kent karşıtı söylem (antitez) oluşturmanın aracı olmuştur. Bu noktada kentin heterotopyası olarak konumlandırıldığı kuramsal ve ideolojik yaklaşımlar ortaya çıkmıştır. Heterotopya, kendine özgü, kendi dinamikleriyle var olan, salt kendisi için varlı̆̆ını sürdüren mekânlardır. Bu noktada peyzaj, ya sanayi öncesi dönemin dinamiklerini yeniden çağırmak için doğa ya da kır ile özdeşleştirilmiş ya da sanayi kentlerine alternatif bir yaşam kurgusu oluşturacak bir araç olarak idealleştirilmiştir.

Peyzaj mimarlığı disiplininin kurumsallaştığı dönemden günümüze kadar en önemli tartışma konularından biri "kimin için?/ne için?" sorgulaması olmuştur. Ondokuzuncu yüzyılda sanayi kentlerinin sağlıksız yaşam koşullarına karşılık olarak F.L. Olmsted, peyzajın, sağlıksız endüstri kentlerinin bozuk öznesinin benliğini olumlu yönde etkileyecek, sağaltıcı manzarasına tüm halk kitlelerinin erişebileceği, kentin sağlık, kanalizasyon, su koşullarını düzeltebilecek ve kenti değiştirebilecek yönünü vurgular. Olmsted, halk sağlı̆̆, kamusal alan, eşit erişim gibi konuları tartışmaya açarken mesleğin kamuya ve kamusal alana hizmet etmesi gerektiği savunmuştur. Bu sayede, kent ölçeğinde kamu parkları yapılmış, endüstri kentlerinde sağlıksız kanalizassyon, bataklık, yağmur suyu yönetimleri gündeme gelmiş ve peyzaj mimarlığının meslek alanı genişlemiştir. Olmsted, bu peyzajları üretirken kentin yöneticileri ve aristokratları ile işbirliği yapmış, peyzajı, kentsel süreçlerle çalışan bir öge olmasına aracı olmuştur. Yaklaşık otuz yıl sonra G. Eckbo, D. Kiley ve J. Rose, Olmsted'e kamusal alana hizmet etmediği için ağır eleştirilerde bulunan G. Eckbo, D. Kiley ve J. Rose, insan için peyzaj [landscape for living] yaklaşımlarıyla peyzajı modern mimarlık ekolüne yakınlaştırmışlardır. Meslek, yeni bir tanınırlık alanı kazanmıştır. Ancak, dönemin daralan ekonomisinin meslek alanın da kısıtlaması sebebiyle sıklıkla özel bahçe tasarımlarında aktif rol oynamışlardır. Kenti, doğa ile sa- 
ğaltmanın yollarını arayan başka bir isim olan Ian McHarg, peyzajı, biyolojik bir sistem, bilimsel yollarla çözümlenebilir ve kentin gelişmesinde kullanılabilecek bir model olarak tanımlar. Peyzaj planlaması, ekolojik planlama, çevre koruma gibi yaklaşımların tanınmasına sebep olan McHarg'ın analiz yöntemleri hala birçok meslek alanınca kullanışmaktadır. Ancak, McHarg'ın ekolojik planlama yöntemleri aynı zamanda yatırımclar tarafından kentin daha fazla yayılması için en karlı arazilerin keşfedilmesi amacıyla kullanılmıştır. Peyzaj planlaması, kentin büyümesinde katalizörü olarak kullanılmıştır. Günümüze yaklaştı̆̆ımızda, yeni kentsel dinamiklerle, birden çok ölçekte çalışan, ağ mekanlarının boşluklarına sızan dinamik peyzaj tanımı ve pratiklerinin yaygınlaştığını görülmektedir. 1980 sonrası post yapısal çözülmelerin uzantısı olarak doğal-kültürel melez bir yapı olarak biçim değiştiren peyzaj, altyapı ile eşleştirilerek bölgesel-küresel ağlarla ilişkili esnek bir form olarak değerlendirilir. Peyzajın üst ölçeklerle ilişkisi sadece ekoloji ve ekosistemler üzerinden tanımlanmak yerine, her türlü politik, ekonomik, ideolojik, yapısal ağlarla ilişkisi dikkate alınmaya başlanır. Peyzaj, giderek çağdaş kentin küresel, yerel değerleriyle daha çok entegre olmaktadır, marka kentlerin pazarlanan unsurları haline gelmektedir. Her ne kadar peyzajın değişken ve ekolojik bağlamı tasarımlara entegre edilmeye çalışılsa dahi, peyzaj kentleşmesi ve peyzaj altyapıları adı altında peyzaj yeni kentsel süreçlerle çalışabilmek için revize edilmiş gibi gözükmektedir. Kentsel süreçler, tüm boşluklara, tanımsız mekanlara, heterotopyaya sızmaktadır. (Bkz. Şekil 1) 


\begin{tabular}{|c|c|c|}
\hline & KURAM & PRATIK \\
\hline 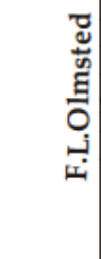 & $\begin{array}{l}\text {-Pitoresk estetik ve güzel manzara } \\
\text {-Halk Sağlığı } \\
\text { - Kanalizasyon sistemi, bataklıklann kurutulması, } \\
\text { yağmur suyu yönetimi } \\
\text {-Sürekliyeşil-mavi alan sistemi } \\
\text { - Sanayi kentlerine yeni bir kentleşme modeli }\end{array}$ & $\begin{array}{l}\text {-Kent parklannın üretilmesi } \\
\text {-Sağhlikh yaşamkoşullarıç̧in parklar } \\
\text {-Avrupa kentleriile yarışan Amerikan kentleri } \\
\text { - Amerikan kamusunun gücünü ve güḑü bir belediye } \\
\text { yönetimi imajı } \\
\text { - Kentin yönetici sınufı ve önde gelen aristokrat sınuf ile } \\
\text { işbirliği } \\
\text {-Pastoral manzara yaratmak için arazi formunun } \\
\text { değiştirilmesi }\end{array}$ \\
\hline 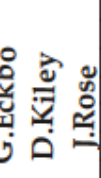 & $\begin{array}{l}\text { Büyük Buhran sonrası demokratikleşme ruhu } \\
\text { Tüm sosyal gruplara hitap eden tasanmlar } \\
\text { - Modem peyzaj mimarhğı yaklaşımı } \\
\text { - Tüm iki boyutlu, tarihsel stillerin reddi } \\
\text { - Desen yerine hacim } \\
\text { - Bitkilerin bilimsel kullanımı }\end{array}$ & $\begin{array}{l}\text { - Modem mimarlikla eşleşen modem peyzaj tasanmlan } \\
\text { - Yeni kentselgelişme alanlanndapeyzajmimarlığı } \\
\text {-Amerikan ekonomisinin tetikleyicisi olan kütle tüketimi } \\
\text { alanlarnda peyzaj tasanmu } \\
\text { - Banliyölerde özel bahçe tasanmlan }\end{array}$ \\
\hline 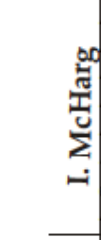 & $\begin{array}{l}\text { Peyzaj ve bilim ilişkisinin kurulması } \\
\text { Peyzaja analitik bakş̧ aģsı } \\
\text { - Peyzaj planlama, ekolojik planlama ve analizler } \\
\text { - Kentteki doğanın korunması } \\
\text {-Planl gelişim } \\
\text { - Peyzajı kentlerin olumsuz koşullarını tedavi } \\
\text { etmesi (Doğa ile Tasanm) } \\
\text {-Sistem teorisi }\end{array}$ & 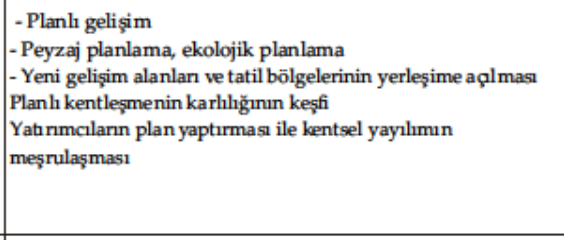 \\
\hline : & $\begin{array}{l}\text { Üst ölçekli, geniş kapsaml, çok katmanl, dinamik } \\
\text { peyzaj } \\
\text { Yaşay an, işleyen, çalı̧̧an bir sistem olarak peyzaj - } \\
\text { - Kenti yönlendiren bir aktör olarak peyzaj } \\
\text { - Süreç odakh tasanmlar } \\
\text { - Çoklu plan şemaları }\end{array}$ & 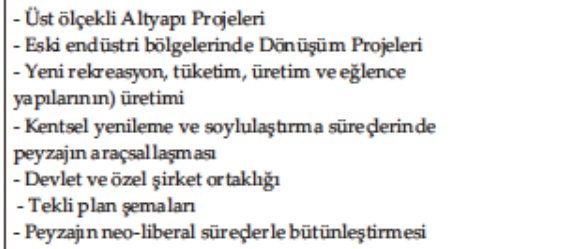 \\
\hline
\end{tabular}

Şekil 1. Peyzaj Mimarlığında peyzajın kuramsal ve mekansal üretim biçimleri.

Elbette, kentin içerisinde yaratılan hiçbir öge, kentsel süreçlerden bağımsız var olamaz. Peyzaj mimarlığ pratiklerinde peyzaj, dönemin kentsel dinamikleri ile birlikte çalışmadan kendini var edemez. Ancak tanımlı araçlar ve yöntemler olmadığı taktirde kentsel dinamikler içerisinde peyzajın nasıl bir rol alacağı muallak kalmaktadır. Kuram ve pratik arasındaki tutarlılığın sağlanması, öncelikle, peyzajın kent ile bilikte çalışan bir sistem olduğunun kabulü ve kuramsal çerçevesinin geliştirilmesiyle başarılabilir. Kuramsal yaklaşımlar, peyzajın kent ile birlikte üretilme biçimlerine çeşitli öngörülerde bulunmak zorundadır. Planlama ve tasarım, öncelikle, kentle entegre olma ve kendine has olma arasındaki bu dengeyi koruyabilmelidir.

Ancak bu, peyzajın kendine has karakterini görmezden gelmek ve tamamen kentsel süreçler, kapitalist üretim biçimleri ve neo liberal doktrinler tarafından asimile edilmesi demek değildir. Aksine, peyzaj, kentin içerisinde, kendi doğasından gelen karakterini ortaya koyabilmelidir. Peyzaj kim/ne için?" sorusunun ötesine geçilip, "nasıl" sorusunun da karşılığının 
hem kuramsal tartışmalarının derinleştirilmesine, hem de mekânsal pratiklerinin olasılıklarının araştırılmasına ve yöntem ve araçlarının geliştirilmesine ihtiyaç duyulmaktadır. İçinde bulunduğumuz dönem, iklim değişikliğinin etkileri, salgınlar, sosyal eşitsizlikler, gıda temini ve lojistiği, savaşlar ve göçler gibi sorunlar ile peyzaj mimarlığı pratiklerini bu sorunlu alanlara zorunlu olarak yöneltmektedir. Bu anlamda peyzajın kentsel dinamikler içerisinde konumlandırılarak, kentlerin karşısına koyulmayan peyzaj yaklaşımları aracılığıyla üretilecek kuramlara ve bu kuramın tanımlanmış yöntemsel araçlar ile kentsel süreçlerin katalizörü olmaya ihtiyacı vardır. 


\title{
Extended Abstract
}

\section{Landscape in-between Theory and Practice: Antithesis to City or Catalyst of Urban Processes?}

*

\author{
Ebru Bingöl \\ ORCID: 0000-0002-7194-0070
}

According to Michel Foucoult (1997), gardens are one of the places of heterotopia that exist in a single space and are incompatible even if they overlap. But is the landscape also in the same classification? Various meanings such as the "other", "feminine and passive", the "anti-thesis to the city", "pastoral aesthetic beauty", and sometimes insecure characters, which were related to the concept of heterotopia, were attributed to the landscape. Although the semantic content varies, the first connotation of what we call landscape in the city is that it is the "other" places of the city. However, the landscape cannot survive unless it is transformed into isotopic spaces accepted by the existing power relations in the city. Landscape has to cooperate with urban processes and behave with the dynamics of the city in order to survive in the city and to go beyond the boundaries of the heterotopia, even if the way it is defined, the "opposite of the city". This article sheds light on the theoretical and discursive ways of positioning the concept of landscape as opposed to the city since the institutionalization of landscape architecture in America at the beginning of the twentieth century. It reveals its relationship with urban paradigms that it cannot stay away from. The aim of the article is to reveal the contradictions between the way landscape is defined in theory and its urban spatial practices.

Although there are various descriptions of landscape, this article focuses on theoretical approaches that have come to the forefront in the process since the beginning twentieth century when the profession of landscape architecture was institutionalized. As the method of the article, literature review and embedded theory research model are used. The article scans and compares the ways in which the concept of landscape is defined as hetero- 
topia, as the other of the city, in the theory and its responses in spatial urban practices.

In response to the unhealthy living conditions of industrial cities in the early twentieth century, F.L. Olmsted (1822-1903) defined the landscape as a landscape equivalent to nature, which will positively affect the self of the distorted subject of the corrupt city. All the masses of people should be able to reach the landscape that heals these health conditions equally. Olmsted argued that the profession should serve to the public and to the public sphere while opening issues such as public health, public sphere, equal access to discussion. However, in working with the city's rulers, Olmsted transferred the advantage of production of the public space into the elites of the city and let the landscape an element guided by urban processes. About thirty years later, for the same reason, Olmsted was subjected to criticism of G. Eckbo, D. Kiley and J. Rose, claiming that he produced the landscape for private and political purposes. G. Eckbo, D. Kiley and J. Rose, who found the solution in the modern architectural school and the lens of the landscape from "for nature" to "for human", stucked into aesthetic arrangements of private persons' gardens without integrated into urban processes. Another name searching for ways to treat the city with nature was Ian McHarg who defined landscape as a biological system, a model that can be scientifically analysed and used for a planned development of the city. However, McHarg's ecological planning methods have also been used by investors to discover the most profitable lands for further spreading the city. One more time, landscape has been the catalyst for the city's growth. As we approach the present day, the definition of landscapes, working on multiple scales and leaking into the gaps of network spaces, has become widespread. Landscape, changed form as a natural-cultural hybrid structure as an extension of post-structural dissolution after 1980. Recently, the relationship of landscape with upper scales is not only defined through ecology and ecosystems, but rather through all kinds of multi-scale political, economic, ideological and structural networks. The landscape is increasingly integrated with the global, local values of the modern city, and became one of the marketed elements of the brand cities. Even though the variable and ecological context of the landscape is tried to be integrated into the designs, the landscape seems to be revised to work with contemporary urban processes under the name of 'landscape urbanism' and 'landscape infrastructures'. Urban processes infiltrate all void, undefined spaces, and the heterotopia. 
Of course, no element created in the city can exist independent from urban processes. In landscape theory, landscape does not prefer to remain wild, it prefers to be a cultural product and a cultural construct to exist in the city. For this reason, it cannot be separated from the dynamics of the city. However, this does not mean ignoring the peculiar character of the landscape and assimilating it entirely by urban processes, capitalist modes of production and neo-liberal doctrines. On the contrary, the landscape should be able to reveal its character in the city by its own nature. There is a need to go beyond the question of "who / what is the landscape for?" and deepen the theoretical debates and investigate the possibilities of spatial practices by asking "how to landscape". Planning and design should be able to maintain this balance, first of all, between integrating with the city and not losing the unique characteristics of landscape.

\section{Kaynakça/References}

Beilin, R. (2013). Book review: The Essential Ian McHarg: Writings on design and nature. F. R. Steiner (Ed), Journal of Agricultural Environmental Ethics, 26. doi:10.1007/s10806-009-9217-y.

Belanger, P. (2012). Landscape Infrastructure: Urbanism beyond Engineering. S. N. Pollalis, D. Schodek, A. Georgoulias, S. J. Ramos (Ed), Infrastructure Sustainability \& Design (s. 276-315) içinde. London: Routledge.

Berman, M. (2004). Katı Olan Herşey Buharlaşıyor. İstanbul: İletişim.

Bingöl, E. (2019). Peyzaj tasarımında arazi kavramına çağdaş yaklaşımlar: Arazi'yi çoklu ölçekler, ilişkiler, süreçler ve deneyimler üzerinden okumak. Y.Aksoy (Ed.), Mimarlıkta Peyzaj Tasarımı (s. 147-176) içinde. Ankara: Nobel Akademik Yayıncilik.

Brenner, N. (2004). New state spaces: Urban governance and the rescaling of Statehood. New York: Oxford.

Cohen, L. (2004). A consumers' republic: The politics of mass consumption in postwar America. Journal of Consumer Research, 31(1), 236-239. doi:10.1086/383439.

Corner, J. (1999). Recovering landscape: Essays in contemporary landscape architecture. New York: Princeton Architectural Press.

Corner, J.(2006). Terra Fluxus. Charles Waldheim (Ed.), The Landscape Urbanism Reader (s 21-33) içinde. New York: Princeton Architectural Press.

Cronon, W. (1996). Uncommon ground: Rethinking the human place in nature. New York: W.W. Norton.

Duany, A.ve Talen, E. (2013). Landscape urbanism and its discontents. BC: New Society Publishers. 
Eisenman, T.S. (2013). Frederick Law Olmsted, Green Infrastructure, and the Evolving City. Journal of Planning History, 4(12), 287-311. doi:10.1177/1538513212474227.

Erten, E. (2009). Algıdan hayalgücüne: resimsi" İngiliz bahçesinde doğa algısı ve kurgusu. Mimarlar Odası Yayınları, Dosya 17: Mimarlık ve Mekan Algısı, 37-46. http://www.mimarlarodasiankara.org/dosya/dosya17.pdf

Farhat, G. (2008). Open space and infrastructure networks in the Val de Bièvre metropolitan area (Paris). Journal of Landscape Architecture, 3, 56-67. doi:10.1080/18626033.2008.9723396

Foucault, M. (1997). Of other spaces: Utopias and heterotopias. N. Leach (Ed.), Rethinking architecture- a reader in cultural theory (s. 329-357) içinde. Londra: Routledge.

Field Operations, (2002). Fresh Kills landsfill to landscape design competition design report. New York.

Görmüş, S. (2019). Peyzajın doğa ile akrabalık kombinasyonları üzerine. Peyzaj Eğitim, Bilim, Kültür ve Sanat Dergisi, 1, 1-8. https://dergipark.org.tr/tr/download/article-file/758450

Jackson, J. B. (1984). Concluding with Landscapes. J.B. Jackson (Ed.), Discovering the Vernacular Landscape (s.145-158) içinde. New Heaven: Yale University Press.

Gissen, D. (2009). Subnature: Architecture's other environments., New York: Princeton Architectural Press.

Glaeser, E. L. ve Shapiro, J. (2001). Is there a new urbanism?The growth of U.S. Cities in the 1990s. Harvard Institute of Economic Research Discussion Paper Number 1925. Massachusetts: Cambridge.

Hall, L. (1995). Olmsted's America: An "Unpractical" Man and His Vision of Civilization. Boston, MA: Bulfinch Press.

Harvey, D. (2002). Spaces of Capital: Towards a critical geography. New York: Routledge.

Herrington, S. (2010). The nature of 1an mcharg's science. Landscape Journal, Say1 29. doi:10.3368/lj.29.1.1

Hill, K. (2001). Urban ecologies: Biodiversity and urban design. Case: Downsview Park Toronto, Harvard Design School PRESTEL, 91-101.

Kaplan, A. (2020). Peyzaj(lar)ın dinamik bağlamı üzerinden tasarımı ve (İnter) disipliner boyutu. Y.Aksoy (Ed.), Mimarlıkta Peyzaj Tasarımı (s. 23-42) içinde. Ankara: Nobel Akademik Yayıncılık.

Kaya, M.E. (2017). Peyzaj ve mimarlı̆̆ı üzerine derlemeler, XXI Mimarlık Dergisi. https://xxi.com.tr/i/peyzaj-ve-mimarligi-uzerine-derlemeler.

Koolhaas, R. (1978). Delirious New York: a retroactive manifesto for Manhattan. London: Thames \& Hudson.

Krueckeberg, D.A. (1994). The American planner: Biographies E recollections. New Brunswick NJ: Rutgers CUPR. 
Kwinter, S. (2008). Far from equilibrium: Essays on technology and design culture. Barcelona: Actar.

Lougran, K. (2014). Parks for profit: the high line, growth machines, and the uneven development of urban public spaces. City and Community, 13(1)., 49-68. doi:10.1111/cico.12050.

Lyster, C. (2006). Landscapes of Exchange: Re-articulating Site. C. Waldheim (Ed.), Landscape Urbanism Reader (s. 219-238) içinde. New York: Princeton Architectural Press.

McHarg, I. (1969) Design with Nature. New York: Natural History Press.

McHarg, I. (2006). Ecology and Design. F. R. Steiner (Ed.), The Essential Ian McHarg: Writings on Design and Nature içinde. Washington: Island Press.

McHarg, (1965). Plan for the Valleys vs. Spectre of Uncontrolled Growth. Landscape Architecture Magazine 55(3), 179-181.

Meinig, D W (1979). Introduction. D.W. Meinig (Ed.), The Interpretation of Ordinary Landscapes. Geographical Essays (s. 1-3) içinde. New York: Oxford University Press.

Meyboom, A. (2009). Infrastructure as Practice. Journal of Architectural Education, Alternative Architectures: Alternative Practice, 4(62), 72-81. doi:10.1111/j.1531314X.2009.01006.x

Meyer, E. (1997). The Expanded Field of Landscape Architecture. G. Thompson ve F. Steiner (Ed.), Ecological Design and Planning. (s. 45-79) içinde. New York: John Wiley Press.

Mikesell, M. (1968). Landscape. Sills, D.L (Ed.), International Encyclopedia of the Social Sciences, Cilt 8, (s. 575-80) içinde. New York: Collier and Macmillan.

Molotch, H. (1976). The City as Growth Machine: Toward a Political Economy of Place. American Journal of Sociology 82, 2, 309-332. https://www.journals.uchicago.edu/doi/pdf/10.1086/226311.

Mostafavi, M. (2003). Landscapes of Urbanism. M. Mostafavi ve C. Najle (Ed.), Landscape Urbanism: A Manual for the Machinic Landscape (s. 4-8) içinde. London: Architectural Association.

Mumford, E. (2009). Defining Urban Design: CIAM Architects and the Formation of a Discipline 1937-69. New Haven and London: Yale University Press.

Olmsted, F.L. (1868). Mr. Olmsted's Report (October 1st, 1868).

Olmsted, F. L. (1886). Law Notes on the Plan of Franklin Park and Related Matters. Boston, MA: Park Department.

Olmsted, F. L. (1895). Parks, Parkways and Pleasure Grounds. Engineering Magazine, 9, 253-54.

Pahl, R. E. (1975). Whose city? And further essays on urban society. Harmondsworth: Penguin.

Peck, J., Nik, T., Brenner, N. (2009). Neoliberal Urbanism: Models, Moments, Mutations. SAIS Review 29, 1, 49-66. doi:10.1353/sais.0.0028. 
Quintana, M. (2006, 8 August). Changing Grid: Exploring the Impact of the High Line. Streeteasy. https://streeteasy.com/blog/changing-grid-high-line/

Rogers, E. (2001). Landscape Design: A Cultural and Architectural History. New York: Harry N.Abrams Inc.

Sassen, S. (2005). The Global City: Introducing a Concept, Journal of World Affairs $11(2), 27-43$.

Smith, N. (2006). Yeni Küresellik, Yeni Şehircilik: Küresel Kentsel Strateji Olarak Soylulaştırma, $\quad$ Planlama, 2, 13-27. https://www.spo.org.tr/resimler/ekler/fbce4c1d7c425ba_ek.pdf

Spirn, A. W. (1984). Granite garden: Urban nature and human design. New York: Basic Books.

Spirn, A.W. (1995). Constructing Nature: The legacy of Frederick Law Olmsted. W. Cronon (Ed.), Uncommon Ground: Rethinking the Human Place in Nature içinde. New York: W. W Norton \& Company, Inc.

Spirn, A.W. (2000). Ian McHarg, Landscape Architecture, and Environmentalism: Ideas and Methods in Context. M. Conan (Ed.), Environmentalism in Landscape Architecture içinde. Washington: D.C., Dumbarton Oaks Research Library and Collection.

Strang, G.L. (1996). Infrastructure as Landscape (Infrastructure as Landscape, Landscape as Infrastructure. Places, 3. https://escholarship.org/uc/item/6nc8k21m.

Taylor, K (2008, Ekim). Landscape and Memory: cultural landscapes, intangible values and some thoughts on Asia [Öz]. 16th ICOMOS General Assembly and International Symposium: 'Finding the spirit of place - between the tangible and the intangible, Quebec, Canada. http://openarchive.icomos.org/id/eprint/139/.

Treib, M. (1993). Modern landscape architecture. A Critical Review. Massachusets: MIT Press.

Van Alen Institute, (2000). Park=city : designing Downsview Park, Toronto. New York : Van Alen Institute, Projects in Public Architecture.

Waldheim, C. (2002). Landscape Urbanism: A Genealogy. Praxis: Journal of writing+ building, 4.

Waldheim, C. (2010). On Landscape, Ecology and Other Modifiers to Urbanism. TOPOS, 71.https://scenariojournal.com/article/on-landscape-ecology-andother-modifiers/

Weller, R. (2014). Stewardship Now? Reflections on Landscape Architecture's Raison d'être in the 21st Century. Landscape Journal, 33. doi:10.3368/lj.33.2.85.

Wilson, W H. (1980). The Ideology, Aesthetics, and Politics of the City Beautiful Movement. A. Sutcliffe (Ed.), The Rise Of Modern Urban Planning 1800- 1914 (s. 165-190) içinde. London: Mansell.

Yiğit, B. (2004). Yirminci yüzyıl modern tasarım akımlarının peyzaj tasarımına etkileri Yayınlanmamış yüksek lisans tezi. Ankara Üniversitesi, Ankara. 